Historic, archived document

Do not assume content reflects current scientific knowledge, policies, or practices. 



\title{
EFFECTS OF NITROGEN AND PHOSPHORUS FERTILIZER ON PLANTED PONDEROSA PINE IN WEST-CENTRAL IDAHO
}

Glenn L. Jacobsen, Richard A. Thompson, and Russe11 A. Rykerl

\begin{abstract}
Nitrogen and phosphorus fertilizers were applied to the soil surface in a 2-0 ponderosa pine plantation on the Payette National Forest in west-central Idaho. The study area was located in an Abies grandis/Acer glabrum habitat type on a basalt soil. The fertilizer treatments did not increase survival or growth of the trees, nor did they increase the amount of competing vegetation. The only significant response was a reduction in survival caused by the high level nitrogen treatments.
\end{abstract}

KEYWORDS: fertilization, Pinus ponderosa, plantation, nitrogen, phosphorus

In recent years, planted ponderosa pine (Pinus ponderosa Dougl. ex. Laws.) has survived consistently well on the Payette National Forest, and most of the future improvement in pine plantations will come by increasing growth.

Increased growth of seedlings in the first three to five growing seasons would provide benefits in addition to increased wood production. It would shorten the time the trees are susceptible to damage by grazing livestock, thus shortening the time livestock must be excluded from a newly planted area. It would also improve esthetics by shortening the time between logging and the reappearance of trees.

${ }^{l}$ Respectively, silviculturist, Payette National Forest; soil scientist, Clearwater National Forest; and research silviculturist, Intermountain Forest and Range Experiment Station, located in Boise, Idaho. 
Fertilization is one means of increasing tree growth. It is an accepted forest management practice in some areas of the United States where low levels of one or more mineral nutrients are responsible for slow tree growth. Although little fertilization has been done in the west-central Idaho area, we have observed numerous examples of increased tree growth from seedlings planted in or near burned slash piles. Increased growth may have been due to increased nutrients, increased moisture, lack of competition, or a combination of these items.

To find out if increased nutrients were responsible for increased growth, we began a fertilization trial in 1975 on the Payette National Forest in west-central Idaho. Only nitrogen (N) and phosphorus (P) were tested because they were the elements believed most likely to achieve a response on the planting site. We designed the study to determine the effects of $\mathrm{N}$ alone, $\mathrm{P}$ alone, and $\mathrm{N}$ and $\mathrm{P}$ combined on tree growth and on competing vegetation.

\section{STUDY AREA}

The study area was a clearcut unit on the New Meadows Ranger District, Payette National Forest. Slash was piled and burned and the site prepared in 1974. The unit was planted to 2-0 ponderosa pine seedlings in spring 1975. Plots were positioned midslope on a northeast aspect with a slope of about 25 percent. The habitat type was Abies grandis/Acer glabrum. ${ }^{2}$ Elevation of the unit is 5,000 ft (1 $500 \mathrm{~m}$ ) above sea level.

The soils are developing from basalt materials of the Columbia River formation. They have ochric epipedons, cambic horizons, frigid soil temperature, and udic moisture regimes. They belong to the fine loamy mixed frigid family of Typic Dystrochrepts. Surface horizons are dark brown to very dark grayish brown silt loams with weak granular to coarse, weak subangular blocky structure; they are nonsticky and slightly acid. Subsoil horizons are dark yellowish brown, gravelly silt loams and silt loams; they are coarse weak to moderate subangular blocky structure, nonsticky, and medium to slightly acid. Soil depths average 45 inches $(114 \mathrm{~cm})$.

These soils represent soils commonly and widely found throughout the western Payette National Forest. Soil textures are favorable for good moisture-holding capacities, and parent materials supply "adequate" amounts of soil nutrients. Suspected natural state nutrient deficiencies are limited to nitrogen.

Soil compaction measurements with an air permeameter were conducted on an adjacent unit. Environmental and logging conditions are nearly identical. Average space was 19 percent near the surface and 16 percent for subsoils. Both values are above the minimum 15 percent guide, and no growth reductions were anticipated due to soil compaction.

No precipitation measurements were available for the site. The nearest precipitation information available was taken for a 15-year period from four gages located approximately 8 to 10 air miles to the north. Elevations of the gages varied from 4,173 to $5,510 \mathrm{ft}$ ( 1272 to $1679 \mathrm{~m}$ ) above sea level. Annual precipitation for the study area is about 38 inches $(96 \mathrm{~cm})$. Average precipitation for June is 2.41 inches $(6.1 \mathrm{~cm})$, July 0.67 inches $(1.7 \mathrm{~cm})$, and August 0.82 inches $(2.1 \mathrm{~cm})$.

${ }^{2}$ Steele, Robert, R. D. Pfister, R. A. Ryker, and J. A. Kittams. 1975. Forest habitat types of Central Idaho. Review draft of a Research Paper, USDA Forest Service, Intermt. For. and Range Exp. Stn., 191 p. 
We auger-planted the 2-0 ponderosa pine seedlings on June 5, 1975, as part of the normal Ranger District reforestation program. The study was superimposed on the plantation. Plot dimensions varied in order to have 12 trees per plot.

We tested nine treatments in a randomized complete block design with five replications. The nine treatments were:

$\begin{array}{ll}\text { Control } & \text { No fertilizer } \\ \mathrm{N}_{1} & 801 \mathrm{~b} / \text { acre of } \mathrm{N} \\ \mathrm{N}_{2} & 2001 \mathrm{~b} / \mathrm{acre} \text { of } \mathrm{N} \\ \mathrm{P}_{1} & 401 \mathrm{~b} / \text { acre of } \mathrm{P} \\ \mathrm{P}_{2} & 1001 \mathrm{~b} / \mathrm{acre} \text { of } \mathrm{P} \\ \mathrm{N}_{1} \mathrm{P}_{1} & 801 \mathrm{~b} \mathrm{~N} \text { plus } 401 \mathrm{~b} \mathrm{P} / \mathrm{acre} \\ \mathrm{N}_{2} \mathrm{P}_{1} & 2001 \mathrm{~b} \mathrm{~N} \text { plus } 401 \mathrm{~b} \mathrm{P} / \mathrm{acre} \\ \mathrm{N}_{1} \mathrm{P}_{2} & 801 \mathrm{~b} \mathrm{~N} \text { plus } 1001 \mathrm{~b} \mathrm{P} / \mathrm{acre} \\ \mathrm{N}_{2} \mathrm{P}_{2} & 2001 \mathrm{~b} \mathrm{~N} \text { plus } 1001 \mathrm{~b} \mathrm{P} / \mathrm{acre}\end{array}$

The lower levels were expected to be adequate to achieve a response on the soils of the study area. The higher levels were included to increase our confidence that enough fertilizer had been applied.

The fertilizers used were urea (46-0-0) and triple superphosphate (0-45-0). The fertilizer was broadcast on the plots October 7, 1975, during a light rainfall. Rain continued that evening so conditions were ideal for movement of the fertilizer into the soil.

Survival, total height, and diameter of the trees were measured in the fall of 1976, 1977, and 1978. An estimate of the percent coverage of competing vegetation was recorded for each plot at the time the treatments were applied and again in the fall of the next 2 years. The data were subjected to analyses of variance. When significant differences due to treatment were found, comparisons among means were made using a sequential method. ${ }^{3}$

\section{RESULTS}

No significant differences were found in third-year heights and diameters among trees receiving the different fertilizer treatments (table 1). The three treatments with the greater rate of nitrogen had an average third-year survival of 84 percent. The average survival for all the other treatments was 97 percent. Treatment $\mathrm{N}_{2} \mathrm{P}_{1}$ (83 percent) was significant1y different from $\mathrm{N}_{1} \mathrm{P}_{1}$ (100 percent). Treatments $\mathrm{N}_{2}$ and $\mathrm{N}_{2} \mathrm{P}_{2}$ just missed being significant at the 95 percent leve1, indicating that the heavy nitrogen applications had a real but detrimental effect on survival. Most of the mortality occurred the first year after treatment.

\footnotetext{
${ }^{3}$ Snedecor, George W. 1956. 534 p. Iowa State Coll. Press, Ames.
} 
Table 1.--Mean third-year survival, total height, and diameter of planted ponderosa pine trees

Treatment

Survival

Percent

$97 \mathrm{ab}^{1}$

$98 \mathrm{ab}$

$85 \mathrm{ab}$

$92 \mathrm{ab}$

$98 \mathrm{ab}$

$100 \mathrm{a}$

$95 \mathrm{ab}$

$83 \mathrm{~b}$

$85 \mathrm{ab}$
Total height ${ }^{2}$

Centimeters

52.2

55.3

51.2

50.9

48.2

51.1

51.9

54.2

56.5
Diameter ${ }^{2}$
Millimeters

15.3

14.9

14.2

14.7

13.8

13.3

14.1

15.9

13.1

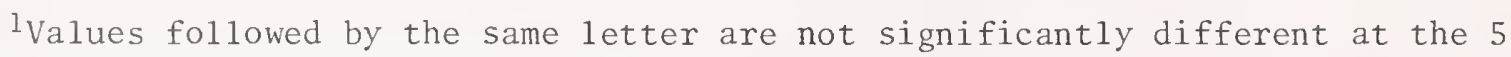
percent level (Snedecor 1956, p. 253).

${ }^{2}$ Analyses of variance tests revealed no significant differences between treatments.

Table 2 shows the mean percent coverage of mineral soil, shrub species, forb species, and grass and sedge species for the end of the 1975 growing season (just before treatment) and of 1976 and 1977. An analysis of variance was calculated for each year for all four categories. The analyses revealed significant differences in treatment effects on the shrubs only, and only in the second year, 1977 . P1ots treated with $\mathrm{N}_{2} \mathrm{P}_{2}$ had significantly less shrub coverage at the end of the 1977 growing season than plots receiving $\mathrm{N}_{1}, \mathrm{~N}_{2}$, and $\mathrm{N}_{2} \mathrm{P}_{1}$ treatments. However, none of the fertilizer treatments had shrub coverages significantly different from the untreated plots.

The distribution of the competing vegetation was more closely related to position within the study area than to fertilizer treatments. Plots in blocks located on lower and midslope positions developed significantly higher coverage of grasses and sedges than upper slope plots. In contrast, forb species were more prevalent on upper slope plots. No significant differences existed in the distribution of shrubs and exposed mineral soil between blocks.

The results indicate that growth of planted ponderosa pine on Abies grandis/Acer glabrum habitat type in west-central Idaho cannot be increased by these fertilizer treatments. Even the competing vegetation was not increased. Why the lack of response is not known, but we think it is because adequate $\mathrm{N}$ was already available to meet ponderosa pine requirements. Moisture was not likely limiting since the soils have a udic moisture regime. The explanation of the increased growth associated with burned slash piles will require further research. 


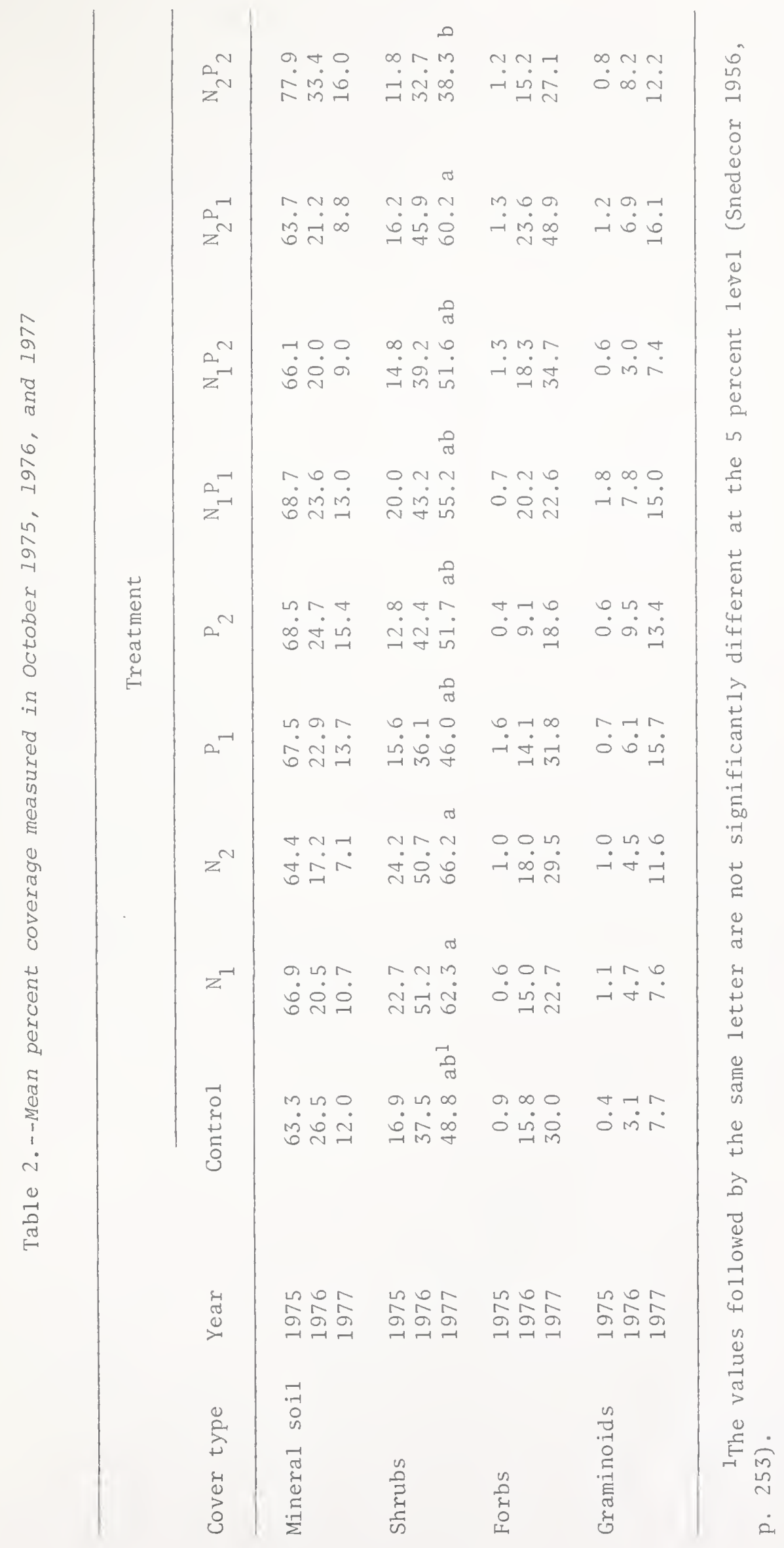


The Intermountain Station, headquartered in Ogden, Utah, is one of eight regional experiment stations charged with providing scientific knowledge to help resource managers meet human needs and protect forest and range ecosystems.

The Intermountain Station includes the States of Montana, Idaho, Utah, Nevada, and western Wyoming. About 231 million acres, or 85 percent, of the land area in the Station territory are classified as forest and rangeland. These lands include grasslands, deserts, shrublands, alpine areas, and well-stocked forests. They supply fiber for forest industries; minerals for energy and industrial development; and water for domestic and industrial consumption. They also provide recreation opportunities for millions of visitors each year.

Field programs and research work units of the Station are maintained in:

Boise, Idaho

Bozeman, Montana (in cooperation with Montana State University)

Logan, Utah (in cooperation with Utah State University)

Missoula, Montana (in cooperation with the University of Montana)

Moscow, Idaho (in cooperation with the University of Idaho)

Provo, Utah (in cooperation with Brigham Young University)

Reno, Nevada (in cooperation with the University of Nevada)

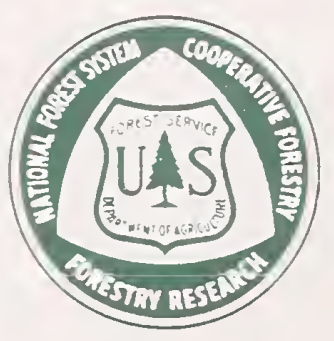

